\title{
Literary Geographical Gene in The Plumed Serpent*
}

\author{
Di Yang \\ School of Foreign Languages \\ Hubei University of Chinese Medicine \\ Wuhan, China
}

\author{
Ya Liu** \\ Department of Art \\ Wuhan University \\ School of Foreign Languages \\ Hubei University of Chinese Medicine \\ Wuhan, China \\ **Corresponding Author
}

\begin{abstract}
British novelist D.H.Lawrence's creations undergo major changes after the World War I, and his works were turned from realism to myths and fables. The geographical natural environment of Mexico made him create The Plumed Serpent. The Geographic Gene, the "primitive image" of Mexican Indians, gives a mysterious image to Lawrence. Lawrence evinces an obvious concern with the duality primitivism-civilization, or rather with the contrast between the Western world and so-called "primitive societies". This preoccupation with primitivism should be viewed as the natural escapist tendency of a society which sought within foreign cultures its own lost stability and purposiveness. It seems that in the three stages of the development of Lawrence's thought, The Plumed Serpent is an important link point for the past and the future, which is an inevitable stage in the exploration of Lawrence's salvation thought, and plays an important role in the study of Lawrence's creation.
\end{abstract}

Keywords-literary geographical gene; The Plumed Serpent; Lawrence; primitive image

\section{INTRODUCTION}

As an outstanding novelist of the 20th century in the UK, Lawrence has a certain position in the minds of Chinese readers. With the deep understanding of Lawrence, more and more people have conducted multi-level and multi-angle research on him and his works. There have been a lot of remarkable monographs and commentaries on Lawrence, his novels are generally divided into four periods. The first period (1906-1913), the early stage of creation, masterpieces are White Peacock, The Intruder and Son and Lovers; the second period (1913-1920), the maturity stage, his masterpieces include The Rainbow, Women in Love and The lost Girl; the third period (1920-1925) is the turning stage, including Aaron's Rod, Kangaroo, The Plumed Serpent; the fourth period (1925-1930): the returning stage, the masterpiece is Lady Chatterley's Lover. After the World War I, Lawrence's creations undergo major changes, and his works were turned from realism to myths and fables. Because the most brutal war in human history has caused Lawrence to lose confidence in European civilization, he should find new ways of human resurrection outside of European civilization. Therefore, he began a long-term

*Supported by project of Humanities and Social Sciences of Hubei Province in 2015 (15Y085) wandering career. He and his wife, Frida, left the UK and drifted for ten years in Italy, Ceylon, Australia, the United States, etc., and their exploration also came out of the pure spiritual realm, out of European Civilization. The geographical natural environment of Lawrence's wandering countries such as Italy, New Mexico, and Australia is very different from that of the UK, which has had a huge impact on the creation of its works.

\section{The CREATIVE BACKGROUND OF THE PLUMED SERPENT AND THE TRANSFORMATION OF LAWRENCE'S CREATIVE STYLE}

Lawrence's novels never win with the complicated plots, as does The Plumed Serpent. The work begins with the 40year-old Irish widow Kate. She was disillusioned with Western civilization and came to Mexico to find a new life, but was involved in a local resurrection of ancient Indian religion. The leader of the movement was Don Ramon Carrasco, who was born in the Spanish aristocracy and was educated in the United States; the deputy leader was Cipriano, an Indian with an army. They revived the Roman Catholic Church by resurrecting the ancient Aztec Indian Quetzalcoatl, and make people regain their vitality. Kate was moved by Ramon's preaching and became the incarnation of the goddess Marion, the goddess of war, but she has not been able to get rid of her inner contradictions. On the one hand, she is attracted by the great primitive vitality of the teachings and rituals of this feather-snake, and on the other hand, she is completely irrational and almost savage (such as the brutal and bloody religious rituals of the traitors during the celebration) Resentful. More importantly, following the teachings of Ramon means denying self-worth and giving up self-will and freedom. This is unacceptable to a woman who has been influenced by Western culture for more than 40 years. Kate was moved by Ramon's preaching and became the incarnation of the goddess Marion, the goddess of war, but she has not been able to get rid of her inner contradictions. On the one hand, she is attracted by the great primitive vitality of the doctrines and rituals of this Quetzalcoatl, and on the other hand, she is resentful of their irrational, almost barbaric behavior (such as the brutal and bloody religious execution of the traitors during the celebration). More importantly, following the teachings of Ramon means denying self-worth and giving up self-will and 
freedom, which is unacceptable to Kate. The Plumed Serpent is an open-ended: Kate is leaving or staying still waiting for the reader to guess. So, why did Lawrence change the style of the previous period and suddenly indulge in the mysterious Indian culture? There are many reasons. The novel was created in 1924 when he was living in Mexico. It is from this book that Lawrence discovered the material of his Mexican novel The Plumed Serpent. In order to find a place to write, he and his wife, Frida, moved to the shores of Lake Chapala and lived with Native Americans. In her memoirs, Frida wrote: "We have crossed the misty Lake Chapala and went to an indigenous village where they made Mexican-style flower scarves; they dyed the wool and then on weaved on a simple loom. Lawrence designed some patterns to make a scarf, as in the case of The Plumed Serpent... Lawrence's imagination in The Plumed Serpent is closely linked to everyday life, and everyday chores and imagination are intertwined" [1]. There is also stronger evidence: Lawrence has witnessed the dance of the Indians. In his travel notes, he wrote:

"I will never forget the Indian dance that I saw in St. Jeronim: the man's hips lined up in a fox skin, and the woman held the seeded plant behind. The man's hair flying in the wind. The Cretans thought that men's long hair is a sacred thing, and the Indians still maintain this tradition. I will never forget the dancer's engrossed expression, so serene, the rhythm of the dance is so gentle. There is no beginning and no end, and the continuous steps are so steady and silent. The whole movement is always toward a solid earth, which is completely different from the kind of upright posture of the Dionysian or Christian Carnival. I will never forget that the men sing in a low voice with the drums, the songs are ups and downs, the deepest voice I have heard in my life, even deeper than the thunder and the roar of the waterfalls in the high notes. That is the wonderful, deep voice that people make when they call in the unfathomable abyss" [2].

Combined with the depiction of Indian dance in the seventh chapter of The Plumed Serpent, it is not difficult to find that Lawrence has almost completely moved the Indian dance scene he saw into the novel. Thus, the most direct factor leading to creation is the written information about the Indian feather snake and the contact with the Indian culture in the author's actual life.

In addition, there is a psychological background that cannot be ignored: The First World War has caused Lawrence to completely disillusion the Western bourgeois democracy and Christian values. He wants to find a place that is not heavily polluted by industrial civilization and Christian culture. This place preserves the original nature of human beings and the ability to save humans whose vitality is shrinking. Lawrence once said in his essay: "Escape, escape our lives. Go over a horizon and enter another life" [3]. Lawrence is a writer with a sense of urgency and a sense of salvation. It is this war that has strengthened his belief in establishing his ideal country, which also becomes the starting point for his new life in a foreign country. The Mexican Indian culture is the method of salvation he has been searching for. Mexico is one of the centers of ancient civilizations of American Indians. The famous Mayan culture and Aztec culture were created by Mexican ancient Indians. In 1928 he recalled his first coming to New Mexico in 1922: "The moment I saw the brilliant, proud morning shine high up over the deserts of Santa Fe, something stood still in my soul, and I started to attend...In the magnificent fierce morning of New Mexico one sprang awake" [4]. The full effect was not instantaneous and Lawrence finally put his own ideal world in Mexico. He wrote in New Mexico: "The experience in New Mexico was the biggest shock that the outside world had given me. It changed me forever. It sounds strange, but it is New Mexico that has freed me from the era of our civilization, the era of material and machine development" [5]. This is an admiration for Mexican culture, because it has brought Lawrence to a new spiritual renewal, which has led to the idea of reviving ancient civilizations to save mankind. This ancient civilization is not a Christian culture, but an Indian religion and culture. As he repeatedly pointed out in The Plumed Serpent: "Christ is not the savior of the Mexican, because he is a god of death... needs a new savior to appear, squeezing the ancient accumulation of their souls and bringing them to the sun" [6]. In the beginning, Lawrence began with his subjective ideals and discovered his own teachings in Indian culture. From the initial understanding of Indian culture, he became deeply impressed by its civilization. The ancient civilization of Indians shocked him and flowed into his blood. In his travels, New Mexico, he wrote: "In fact, before I came to New Mexico and delved into the ancient races there, I never had an eternal sense of religion... it was embodied in the red Indians that it did not feel in Hindus, Catholics in Sicily, and Sinhalese in Ceylon" [7]. With a strong life impact on the rough terrain of the Americas, the Indian form of life and religious rituals, with a worship of the Indian spirit and religion, with the pursuit of primitivism, Lawrence devoted himself to the writing of Indian works.

\section{THE LiterARY GeOGRAPHICAL GENE — THE "PRIMITIVE IMAGE" IN THE PluMED SERPENT}

Literary geography criticism is a method of criticism and research literature as a new direction of comparative literature research in China. It is also a new field of criticism and literature research, a branch of Chinese comparative literature research. Literature is inseparable from three factors: emotion, imagination and form, but if it is related to one of the factors, it can be regarded as a literary phenomenon. Literature is a unique product of human society. However, the records related to humans are not literature, and literature should be the aesthetic theory of the human being. Therefore, literature is inseparable from human and aesthetics, it is impossible for us to leave the natural environment and exist independently. Anyone can only be born in a certain natural environment, grow up and develop in a specific natural environment. It is also the writer's aesthetics of people, things and scenery. This kind of aesthetics is also carried out in a specific natural environment. The "original aesthetics" in the vacuum does not exist. Therefore, the growth of any writer cannot leave a specific natural geographical environment, and the creation of any work can only occur in a specific natural environment. 
Therefore, we call this innate factor the literary geographical genes.

Literary geographical genes can be verified in two aspects: the natural living environment in which the writer grew up, and the natural landscape environment he later grew up, including the writing environment that influenced his creation. One is through the research of various geographical factors in his works, indicating that its specific geographical genes exist and have an impact. The "geographical imagery" of literary ontology is the result of geographical genes and can also be used to illustrate the constraints of geographical genes.

Lawrence evinces an obvious concern with the duality primitivism-civilization, or rather with the contrast between the Western world and so-called "primitive societies". This preoccupation with primitivism should be viewed as the natural escapist tendency of a society which sought within foreign cultures its own lost stability and purposiveness. In The Plumed Serpent, the geographical gene - the "primitive image" of Mexican Indians gives a mysterious image to Lawrence. In Chapter V "The Lake", there are some descriptions about the natural primitive landscape:

"And for the first time Kate felt she has met the mystery of the natives, the strange and mysterious gentleness between a Scylla and a Charybdis of violence; the small poised, perfect body of the bird that waves wings of thunder and wings of fire and night in its flight. But central between the flash of lightning and the break of thunder, the still, soft body of the bird poised and soaring, forever. The mystery of the evening-star brilliant in silence and distance between the downward-surging plunge of the sun and the vast, hollow seething of inpouring night. The magnificence of the watchful morning-star, that watches between the night and the day, the gleaming clue to the two opposites" [8].

The Mexican primitive image cut Kate off all the mechanical Western so-called civilized world. She would be alone in her own milieu, to shut doors of iron against the mechanical world. Not to look out any more on to that horrible machine of the world, to let the sunwise world steal across her, with the big sun and the stars like a tree holding out its leaves. For Indians believe at the heart of the earth sleeps a great serpent, in the midst of fire. "The snake of the world is huge, and the rocks are his scales, trees grow between them...So vast a serpent you walk on, this lake lies between his folds as a drop of rain in the folds of a sleeping rattlesnake. Yet he none the less lives. The earth is alive" [9]. From these descriptions, it shows Lawrence himself also cried aloud to the greater mystery, the higher power that hovered in the interstices of the hot air, rich and potent. Some sort of Mexico wild strength attracted him to escape the hatred Western mechanical world.

\section{THE INFLUENCE OF LiTERARY GEOGRAPHICAL GENE ON LAWRENCE'S CREATIVE STYLE AND THOUGHT}

For analyzing the literary geographical gene, only by combining the writer with his works could we grasp and recognize the core point of view. The most important way of reflecting geographical factors is from literary works, which can be explained in various documents related to writers. From the aesthetic analysis of literary texts, we can find out what roles the geographical gene have played in the process of literary creation and what is the meaning of them? The roles of geographical genes are not always positive and constructive. Sometimes it may be destructive and not unified with the spirit of the subject. In the process of studying the literary geographical gene, it is of utmost importance whether the aesthetic perception of literary works is accurate or not. Is the geographical gene in the writer static or dynamic? Is it the unchanging source of life, or is it the evolving river of life? It is a unity of change and unchanging. Then, if the writer constantly changes the living environment as the needs of life, then new physical and geographical factors will be added, and the original geographical genes will collide to produce new quality, and will always change. However, they all exist and develop around the geographical genes formed in the early years. Therefore, geographical genes are the unity of dynamics and statics. How do geographical genes and literature relate to each other? Literary geographical genes are mainly related to the works through the literary way of the writer in the process of writing. Except for the case of collective creation, as long as it is an individual creation, all writers' thoughts are poured into new works through the expression of his own language. The writer's thoughts, imagination, emotion, feeling, temperament, personality, and style, including the shortcomings of the writer himself, will naturally exist in the specific literary works. Therefore, the most direct and reliable method is to find geographical genes from literary works through aesthetic perception. The writer's background information can prove the existence of geographical genes in the works and the geographic genes that the writers have preserved and precipitated for many years.

Like other modernist writers of the twentieth century, Lawrence believes that the human spirit is in crisis and that the world is in ruin. He has been thinking about how the soul of modern death can be rehabilitated and painstakingly pursues the specific way of resurrection. In the early works represented by The Rainbow and Women in love, he is passionate about the theme of the conflict between industrial civilization and nature, the theme of gender relations, and the theme of death and regeneration. Lawrence's explorations for finding a way out for humanity are also concentrated in the spiritual realm, in the realm of European civilization. During this period, he is not desperate for the modern civilization of mankind. This is the first stage of his thought exploration. In the six years after the World War I, his exploration entered the second stage. Correspondingly, major changes have taken place in his creation, and the work has been further turned from realism to myths and fables. The Plumed Serpent is an example. Because the most brutal war in human history has caused Lawrence to lose confidence in European civilization, he should find new ways of human resurrection outside of European civilization. To this end, he began a long-term wandering career, and his exploration also came out of the pure spiritual realm, out of European civilization. During this period, he was exposed to some exotic ancient cultures that existed in contrast to European culture, such as Indian culture and West African culture. The 
strangeness, uncertainty and mystery of these exotic cultures make him fascinated. Their uninterpretable nature contains infinite vitality and can awaken the vitality of those who are stifled by industrial civilization. Thus, Lawrence's exploration at this stage is naturally blended with these ancient exotic cultures, which serve as the savior of the author's resurrection of human vitality. So, Lawrence entered the final stage of thought exploration. This is a negation of a higher level of negation after summing up the gains and losses of the previous two stages. The Lady Chatterley's Lover is a concentrated expression of this idea. The author abandons the path of redemption of mankind purely by mythology and religion, and still returns to the pre-existing reality of sexuality, but this is not a simple return, but rather the original religious color in the latter stage: he sublimates his sexuality to the realm of sexual education. It is a kind of returning to the origin, it is a worship of sex, showing a strong sexuality.

\section{CONCLUSION}

It seems that in the three stages of the development of Lawrence's thought, The Plumed Serpent is an important link point for the past and the future. Its appearance is by no means accidental, and it is not the mystery of Lawrence's thought. On the contrary, it is an inevitable stage in the exploration of Lawrence's salvation thought, and plays an important role in the study of Lawrence's creation. Correspondingly, the theme of the novel in this period contains many anthropological and mythological elements, full of the mysterious colors of primitive image and culture. However, for a writer like Lawrence who devoted his life to exploring the path of human salvation, this path of revival of ancient religion to save mankind is not the ultimate in his exploration. Perhaps the writer finally realized that this path seemed beautiful but illusory, and realized that the religious fanaticism he showed was unrealistic.

\section{REFERENCES}

[1] Brenda Maddox, D.H.Lawrence: The Story of A Marriage, New York: Simon \& Schuster, 1994, p302.

[2] Tracy, Jr, Billy T, D.H Lawrence and the Literature of Travel, Amm Arbor: UMI Research Press, 1983, p145.

[3] Bloom, Harold. (ed.), D. H. Lawrence (Modern Critical View), New York: Chelsea House Publishers, 1986, p158.

[4] D.H Lawrence, Selected Critical Writings, Oxford and New York: Oxford University Press, 1998, p142.

[5] D.H Lawrence, Selected Literary Criricism, London: Heinemann Educational Books Ltd, 1982, p139.

[6] D.H Lawrence, The Plumed Serpent, Beijing: Central Compilation \& Translation Press, 2011, p145.

[7] D.H Lawrence, Morings in Mexico, Penguin Travel Library,1986, p144.

[8] D.H Lawrence, The Plumed Serpent, Beijing: Central Compilation \& Translation Press, 2011, p115.

[9] D.H Lawrence, The Plumed Serpent, Beijing: Central Compilation \& Translation Press, 2011, p250. 